\title{
ADMINISTRASI HUBUNGAN SEKOLAH DAN MASYARAKAT
}

\author{
Resky Gerhana Hidayatullah \\ Universitas Negeri Padang \\ Indonesia \\ E-mail : gerhanaresky@gmail.com
}

\begin{abstract}
Abstrak- The problems facing education in Indonesia is the equity, quality and relevance of education and management. Centralized management education cannot accommodate the differences in diversity or interest, whether for schools and learners, and reduce public participation in the educational process. This study aims to determine: (1) Forms of cooperation activities in elementary schools with community. (2) The implementation of cooperation with the community in elementary school, and (3) Barriers faced by the principal in the implementation of cooperation with public schools in realize the Quality Improvement Management. This research included in the descriptive research by illustrating what it is about the variables, symptoms and conditions of cooperation with public schools in the management of quality improvement in Primary Schools. From the results of this study can be found that: (1) Forms of cooperation activities and community schools, namely: health students, textbook procurement, the procurement of media and visual aids, procurement of equipment and practice lessons, activities marching band, scouts, commemoration of national holidays, procurement of scholarship, (2) The implementation of the activities have come from a source of funds is done by buying at the store by the schoo,
\end{abstract}

Keywords: Schools Cooperation, community, management of quality improvement

\section{PENDAHULUAN}

Pendidikan merupakan upaya untuk membentuk manusia yang berilmu, bermoral dan berkarakter. Selain mendapatkan pendidikan tentang ilmu umum, peserta didik juga mendapatkan ilmu agama yang cukup.

Sekolah bukan hanya mendidik untuk pandai dalam hal ilmu pengetahuan umum, tetapi juga dalam hal ilmu agama dan karakter. Pendapat tersebut didukung dengan pendapat dari Purwanti (2014) bahwa "faktor pendukung dalam mengimplementasikan pendidikan karakter adalah lingkungan sekolah yang kondusif, strategis dan mempunyai hubungan yang baik dengan masyarakat".

Nata (2008:195) berpendapat bahwa "pendidikan yang islami adalah pendidikan yang mendasarkan konsepsinya pada ajaran tauhid". Pendidikan yang islami merupakan pendidikan yang mengefektifkan nilai-nilai agama untuk membentuk akhlak peserta didik agar sesuai dengan ajaran agama. Sekolah merupakan tempat pembinaan dan pengembangan pengetahuan, kebudayaan, ketrampilan, ketaqwaan, kecerdasan, dan perilaku yang sesuai dan dikehendaki oleh masyarakat dimana sekolah itu berada.

Sekolah adalah lembaga yang secara formal dan potensial memiliki peranan paling penting dan strategis bagi pembinaan generasi muda, termasuk bagi siswa Sekolah Dasar. Dari sekolah inilah peningkatan kualitas sumber daya manusia dimulai, melalui pendidikan yang berjangka waktu panjang. Peningkatan mutu pendidikan tidak bisa lepas dari peranan masyarakat yang diharapkan membantu dan bekerjasama dengan sekolah agar program sekolah berjalan lancar dan lulusan yang dihasilkan memenuhi kebutuhan masyarakat.

Permasalahan yang dihadapi dunia pendidikan di Indonesia adalah pemerataan, mutu dan relevansi serta manajemen pendidikan. Manajemen sentralistik yang selama ini kita laksanakan kurang mendorong terjadinya demokratisasi dan desentralisasi penyelenggaraan pendidikan. Manajemen pendidikan yang sentralistik tidak dapat mengakomodasi perbedaan keragaman atau kepentingan baik untuk sekolah maupun peserta didik, serta mengurangi peran serta masyarakat dalam proses pendidikan. Berbagai usaha telah dilakukan untuk meningkatkan mutu pendidikan nasional, antara lain melalui berbagai pelatihan dan peningkatan kompetensi guru, penyempurnaan kurikulum, pengadaan buku-buku dan alat- alat pelajaran yang menunjang proses $\mathrm{KBM}$ (Kegiatan Belajar Mengajar) pengadaan sarana dan prasarana pendidikan serta peningkatan anggaran pendidikan.

Namun demikian berbagai upaya belum menunjukkan adanya keberhasilan yang memuaskan dalam peningkatan kualitas baik jangka pendek maupun jangka panjang. Beratnya tantangan yang dihadapi oleh dunia pendidikan ini mendorong berbagai kalangan baik pemerintah, praktisi maupun pakar pendidikan untuk mencari solusi untuk memecahkan masalah. Salah satu alternatif adalah diterapkannya Manajemen Peningkatan Mutu. Manajemen Peningkatan Mutu adalah suatu model manajemen yang memberikan otonomi lebih besar kepada sekolah dan mendorong pengambilan keputusan partisipatif yang melibatkan secara langsung semua warga sekolah (guru, siswa, kepala sekolah, karyawan) orang tua siswa dan masyarakat untuk meningkatkan mutu sekolah.

Dengan otonomi yang lebih besar, maka sekolah memiliki kewenangan yang besar pula dalam mengelola sekolahnya, sehingga sekolah lebih mandiri. Dengan kemandirian itulah sekolah lebih dapat berupaya dalam mengembangkan program- 
program yang sesuai dengan kebutuhan dan potensi yang dimiliki. Dengan pengambilan keputusan partisipasi maka rasa memiliki warga sekolah dapat meningkat, peningkatan rasa memiliki akan menyebabkan rasa tanggung jawab, dan peningkatan rasa tanggung jawab akan meningkatkan dedikasi warga sekolah terhadap sekolahnya.

Diharapkan dengan adanya kerjasama yang harmonis antara sekolah dan masyarakat, maka tujuan pendidikan akan dapat tercapai sesuai dengan harapan orang tua, masyarakat, dan sekolah.

\section{METODE PENULISAN}

Metode penulisan artikel ilmiah ini menggunakan metode kualitatif, sebagai objek kajiannya merupakan jurnal nasional dan buku. Tidak dimaksudkan untuk menguji hipotesis tertentu tetapi hanya menggambarkan apa adanya tentang variabel, gejala dan keadaan tentang kerjasama sekolah dengan masyarakat dalam manajemen peningkatan mutu.

\section{KaJian Teori dan Pembahasan}

\section{A. Kerjasama Sekolah dengan Masyarakat}

Kerjasama adalah satu bentuk partisipasi untuk memperoleh pengertian, dukungan kepercayaan dan penghargaan dari masyarakat umum. Partisipasi tersebut antara lain berujud bantuan administrasi secara langsung dan tidak langsung yang mendukung penyelenggaraan pendidikan di sekolah. Adanya kerjasama sekolah dengan masyarakat itu sebagai usaha untuk mewujudkan tujuan pemerintah dalam pendidikan yaitu mencerdaskan kehidupan bangsa. Untuk mencapai tujuan itu harus ada hubungan yang harmonis antara lembaga pendidikan dengan masyarakat.

Menurut B. Suryosubroto (2004: 16) kerjasama ini dikarenakan adanya;

a. Kesamaan Tanggung Jawab

Di dalam GBHN ditegaskan bahwa pendidikan adalah tanggungjawab bersama antara pemerintah, orang tua dan masyarakat. Masyarakat terdiri atas kelompok-kelompok dan individu-individu yang berusaha menyelenggarakan pendidikan atau membantu usaha-usaha pendidikan. Dalam masyarakat terdapat berbagai organisasi penyelenggara pendidikan, organisasi keagamaan, organisasi olahraga, atau organisasi kesenian yang bergerak dalam usaha pendidikan. Dalam masyarakat juga terdapat individuindividu yang bersimpati terhadap pendidikan di sekolah.

b. Kesamaan Tujuan

Sekolah menghendaki agar para siswa kelak menjadi manusia pembangunan yang Pancasilais. Masyarakat juga menghendaki agar semua warga negara menjadi manusia pembangunan yang Pancasilais. Individu yang Pancasilais diharapkan datang dari sekolah. Oleh karena itu, antara sekolah dan masyarakat harus mempunyai kesamaan tujuan. Wujud dari kerjasama adalah; (a) Hubungan sekolah dengan orang tau murid harus dipelihara sebaikbaiknya, (b) Untuk mewujudkan hubungan tersebut, perlu dibentuk satu panitia pemeliharaan sekolah yang terdiri atas beberapa orang tua murid, dan (c) Susunan dan kewajiban panitia pembantu pemeliharaan sekolah ditetapkan oleh Mendikbud.

Hubungan sekolah dengan masyarakat serta hubungan sekolah dengan orang tua murid, pada hakikatnya adalah sarana yang cukup mempunyai peran menentukan dalam usaha pembinaan, pertumbuhan, dan pengembangan murid-murid di sekolah. Oleh karena itu, hubungan tersebut perlu dibina, dibangun dan dipelihara sebaik-baiknya karena merupakan jembatan saling pengertian sehingga mereka dapat berpartisipasi secara positif dan dapat memberikan dukungan moral material secara ikhlas.

Menurut Suryosubroto (2004: 71) tujuan kerjasama sekolah dengan masyarakat dan orang tua murid adalah: (a) Membantu dan mengisi kegiatan anak di sekolah yang hanya berkisar tujuan, sementara siswa waktunya dihabiskan di rumah dan di masyarakat, (b) Memberikan sumbangan keuangan dan barang, dan (c) Mencegah perbuatan dan tingkah laku yang kurang baik.

Terjadinya hubungan yang baik antara sekolah dengan orang tua murid serta masyarakat, akan bermanfaat bagi sekolah, masyarakat, orang tua murid, dan anak didik sendiri. Peran serta masyarakat berfungsi untuk ikut memelihara, menumbuhkan, meningkatkan dan mengembangkan pendidikan nasional. Bentuk-bentuk kerjasama sekolah dengan masyarakat dalam penelitian ini merujuk pada Pasal 4 PP Nomor 39 Tahun 1992 yang meliputi:

a.Mengikutsertakan wali murid dalam menunjang pelaksanaan pendidikan.

b.Pemberian bantuan tenaga ahli.

c.Mendayagunakan tokoh-tokoh masyarakat untuk turut menunjang pelaksanaan pendidikan.

d.Pengadaan dana dan memberi bantuan yang berupa wakaf, beasiswa, hibah, pinjaman dan bentuk-bentuk lain.

e.Pengadaan dan pengadaan buku pelajaran dan peralatan pendidikan untuk melaksanakan kegiatan belajar mengajar.

Dalam melakukan kerjasama agar mendapat hasil yang memuaskan, maka dipakailah berbagai macam teknik. Teknik kerjasama sekolah dengan masyarakat menurut Suryo Subroto (2004: 65):

a. Melalui Badan Komite Sekolah

Komite sekolah adalah organisasi yang beranggotakan orang tua siswa atau anggota masyarakat yang mempunyai minat terhadap suatu sekolah. Biasanya, setiap sekolah memiliki satu organisasi komite sekolah. Jadi, seorang anggota masyarakat dapat menjadi anggota komite sekolah di beberapa sekolah. Melalui komite sekolah diharapkan bantuan dari masyarakat datang, misalnya berupa uang, alat pendidikan, gedung, dan barang keperluan sekolah. b. Melalui Konsultasi

Sekolah dapat mengadakan konsultasi dengan seorang ahli yang ada di masyarakat, misalnya tentang siswa yang mengalami hambatan. Untuk itu guru dapat langsung berkonsultasi dengan dokter, psikolog, dan sebagainya. Hasil konsultasi tersebut dipakai sebagai pedoman pembinaan siswa di sekolah.

c. Melalui Rapat Bersama 
Sekolah dapat mengundang organisasi perseorangan yang bersimpati terhadap pendidikan untuk rapat bersama dalam rangka membahas suatu masalah. Rapat tersebut dipimpin oleh kepala sekolah atau ahli yang ditunjuk. Dalam rapat itu, misalnya dibahas tentang pendidikan lingkungan agar tercipta pendidikan yang baik atau masalah-masalah lain, seperti cara penanganan masalah kenakalan remaja.

\section{d. Melalui Penyusunan Program Bersama}

Biasanya, sekolah memiliki program tahunan, baik bersifat kurikuler maupun kokurikuler. Tentu saja program sekolah tersebut disodorkan terlebih dahulu kepada masyarakat. Kemudian, masyarakat diminta untuk menyusun program lain yang menunjang program sekolah atau program tambahan untuk mengisi waktu senggang siswa di waktu sore atau malam. Penyusun program bersama sangat penting agar tidak terjadi pemborosan tenaga, biaya, dan program yang tumpang tindih.

e. Melalui Ceramah

Sekolah dapat mengundang seorang ahli untuk memberikan ceramah di sekolah, misalnya mengenai program keluarga berencana atau pokok bahasan lain yang diperlukan siswa. Ceramah dapat diadakan pada waktu libur atau pada sore dan malam. Pokok bahasan yang dipilih sebaiknya permasalahan yang sedang berkembang di masyarakat.

Dalam melakukan kerjasama agar tercapai keberhasilan yang maksimal yaitu tercapai tujuan orang tua dan masyarakat maka ditempuh dari berbagai macam bidang baik dari proses pembelajaran di sekolah maupun melalui berbagai macam kegiatan di luar sekolah. Masyarakat merupakan sumber yang menyediakan peserta didik, guru, sarana dan prasarana npenyelenggaraan sekolah dan peserta dalam proses pendidikan yang mengikuti dan turut mempengaruhi proses pendidikan di sekolah seperti yang tertera dalam Gambar 1.

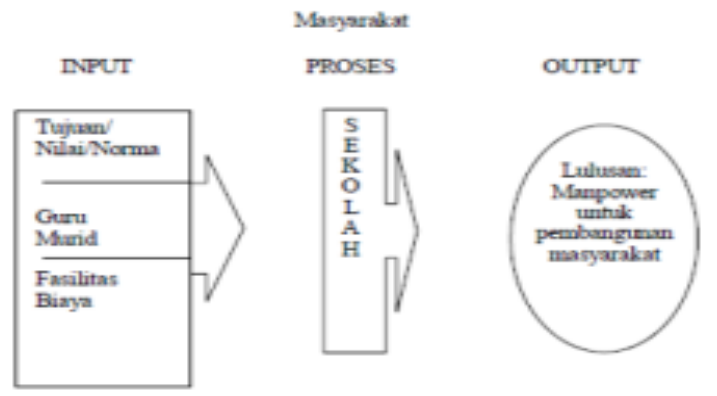

Gambar1. Sistem Hubungan Sekolah dengan Masyarakat

\section{B. Manajeman Peningkatan Mutu Sekolah}

Konsekuensi dari kebijakan otonomi pendidikan, antara lain bahwa sekolah (Sekolah Dasar) sebagai lembaga penyelenggara pendidikan yang menjadi fondasi untuk proses pendidikan pada jenjang yang lebih tinggi, diharapkan akan mampu mengatur dirinya sendiri secara bertanggung jawab dengan memberdayakan seluruh sumber daya yang dimilikinya untuk mencapai tujuan-tujuan sekolah. Di samping itu sekolah dituntut untuk mampu memahami posisi dirinya dan mampu mengambil keputusan yang terbaik atas dirinya sendiri dengan didukung oleh kemampuan manajemen yang handal, dan didukung oleh seluruh warga sekolah dan masyarakat, untuk mewujudkan tujuan yang telah disepakati bersama oleh seluruh warga sekolah tersebut.

Untuk mewujudkan kondisi tersebut, maka pemerintah telah mencanangkan pemberlakuan pola manajemen yang berbasis di sekolah atau Manajemen Berbasis Sekolah (MBS) sebagai pola baru dalam manajemen sekolah, yang secara bertahap diharapkan akan mampu mewujudkan kondisi yang diharapkan tersebut.

\section{IV.KESIMPULAN}

1.Pelaksanaan kegiatan sekolah dengan masyarakat antara lain: pengadaan alat pelajaran dan alat praktek dilakukan dengan cara membeli di toko oleh sekolah, kegiatan penunjang dalam bentuk peningkatan kesehatan siswa dilakukan dengan kerjasama dengan LSM dan masyarakat yang peduli dengan pendidikan, kegiatan dalam bentuk pengadaan buku penunjang bidang studi dilakukan dengan cara memberli pada pedagang yang datang di sekolah, kegiatan ekstrakurikuler pramuka dilaksanakan 1 minggu sekali dengan memberi honor pada pelatih, kegiatan pengadaan media dan alat peraga dilakukan dengan cara membeli di toko oleh sekolah, kegiatan pemberian beasiswa dilakukan kerjasama dengan LSM kepada GNOTA dan dengan pemerintah berupa beasiswa prestasi, kegiatan peninjang dalam memperingati hari besar nasional dilakukan di sekolah dengan menyerahkan dana kepada wali siswa, kegiatan olah raga dilakukan di sekolah dengan tenaga guru olah raga yang dibiayai menggunakan dana sekolah, kegiatan les Bahasa Inggris dilaksanakan di sekolah 1 minggu sekali, kegiatan peringatan hari besar agama dilaksanakan oleh sekolah dengan dana wali siswa, kegiatan ekstrakurikuler

2. Hambatan yang ditemui, diantaranya:

a. Dalam merancang program, pihak sekolah tidak mampu mengusahakan keterlibatan masyarakat dalam merancang kegiatan sekolah dan tidak mempunyai kesempatan dan kemampuan untuk mengumpulkan wali murid. Dari masyarakat, tidak semua anggota masyaralat memiliki kemampuan intelektual untuk memikirkan atau membuat perencanaan dan tidak semua wali murid mempunyai kesempatan untuk ikut bermusyawarah.

b.Dalam pelaksanaan program, pihak sekolah dapat melakukan karena telah terbiasa melaksanakan sendiri sedangkan dari masyarakat diantaranya tidak ada kesempatan berpartisipasi dan kelambatan mengumpulkan iuran.

c.Hambatan yang lain yaitu kurangnya pemanfataan kebun sekolah dan kurangnya lat pendukung

\section{Daftar Pustaka}

Akhmad Sudrajat (2010). Manajemen Peran Serta Masyarakat.

http://akhmadsudrajat.wordpress.com/2010/01 
/10/konsep-dasar-manajemen-peran-sertamasyarakat/

Ngalim Purwanto (2008). Administrasi dan Supervisi

Pendidikan. Bandung : Remaja Rosda Karya.

Suharsimi Arikunto (2002). Prosedur Pelatihan Suatu Pendekatan Praktis. Jakarta: Rineka Chipta.

Suryosubroto (2004). Dimensi-dimensi Administrasi Pendidikan di Sekolah. Jakarta: Bina Aksara. 